\title{
In silico Docking Studies on ATP-Sensitive K+Channel, Insulin Receptor and Phosphorylase kinase Activity by Isolated Active Principles of Stereospermum tetragonum DC
}

\author{
Bino Kingsley ${ }^{* 1,3}$, Sunitha Kumari ${ }^{2}$, Appian Subramoniam ${ }^{4}$, Brindha Pemiah ${ }^{1}$ \\ 'Centre for Advanced Research in Indian system of Medicine (CARISM), SASTRA University, Thanjavur 613 401.TamilNadu, INDIA. \\ ${ }^{2}$ Malankara Catholic College, Mariagiri, Tamil Nadu, INDIA. \\ ${ }^{3}$ School of Pharmacy, KPJ Healthcare University College 71800 Nilai, Negeri Sembilan, MALAYSIA. \\ ${ }^{4}$ Division of Phytochemistry and Phytopharmacology, Tropical Botanic Garden and Research Institute, Palode, Thiruvananthapuram 695562, INDIA.
}

\begin{abstract}
Background: Stereospermum tetragonum is a medicinal plant that grows throughout tropical parts of Indian sub continent, particularly in sandy soils of river beds in Northern India. S. tetragonum is a potential source of metabolites such as coumarines, glycosides, tannins and terpenoids traditionally used in the treatment of Diabetes mellitus. The main objective of the study is to evaluate the interaction of active principles isolated from S. tetragonum with ATP-sensitive $\mathrm{K}+$ channel, Insulin receptor and phosphorylase kinase by in silico docking studies. Methods: Activation by in silico docking studies of ATP-sensitive K+ channel, Insulin receptor, Phosphorylase kinase with1,4a,5,7a-tetrahydro-5-hydroxy-7-(hydroxymethyl)1-(tetrahydro-6-(hydroxymethyl)-3,4,5-trimethoxy-2H-pyran-2-yloxy) cyclopenta[c]pyran-4-carboxylicacid and 5,8-dihydro-7-isopentyl-2,3,5,8tetramethoxynaphthalene-1,4,6-triol isolated from the active fraction by solvent fractionation and chromatographic techniques and characterized with spectral data of water extract of S.tetragonum. Results: The isolated compounds showed better interaction than metformin glide score -2.563 through an extensive in silico docking approach with ATP-sensitive $\mathrm{K}+$ channel. The glide score is $-6.981 \mathrm{Kcal} / \mathrm{mol}$ for compound 1 and -9.425 $\mathrm{Kcal} / \mathrm{mol}$ for compound 2. In Insulin receptor the glide score for standard
\end{abstract}

metformin is -3.359 and for compound 1 is -7.882 and compound 2 is -4.62 . in Phosphorylase kinase the glide score of standard metformin is -4.864 and the glide score for compound 1 is -6.981 and compound 2 is -5.253 with the receptors. Conclusion: The work establishes the isolated compounds from the fraction of $S$. tetragonum as a potential source for Diabetic treatment thus enabling a possibility of this plant as new alternative to existing diabetic approaches.

Key words: ATP- sensitive K+channel, Insulin receptor, Phosphorylase kinase, Stereospermum tetragonum.

Correspondence :

Assoc. Prof. Dr. Bino Kingsley, M.Pharm., Ph.D.,

School of Pharmacy, KPJ Healthcare University College, Lot PT 17010, Persiaran Seriemas, Kota Seriemas, Nilai 71800, Negeri Sembilan, MALAYSIA.

Contact Number: 006-0149431585

E-mail: binokin1975@gmail.com

DOI: 10.5530/jyp.2017.9.23

\section{INTRODUCTION}

ATP-sensitive potassium $\left(\mathrm{K}_{\mathrm{ATP}}\right)$ channels play a central role in glucosestimulated insulin secretion from pancreatic beta cells. Insulin secretion is initiated by closure of the channels and inhibited by their opening. ${ }^{1}$ The beta-cell $\mathrm{K}_{\text {ATP }}$ channel is an octameric complex of four pore-forming, inwardly rectifying potassium-channel subunits (Kir6.2) and four regulatory sulfonylurea-receptor subunits (SUR1). Both Kir6.2 and SUR1 are required for correct metabolic regulation of the channel: ATP closes the channel by binding to Kir6.2, and magnesium nucleotides (Mg-ADP and Mg-ATP) stimulate channel activity by interacting with SUR1. Sulfonylureas stimulate insulin secretion in type 2 diabetes by binding to SUR1 and closing $\mathrm{K}_{\mathrm{ATP}}$ channels by an ATP-independent mechanism. ${ }^{2}$ Insulin receptor belongs to the class of tyrosine kinase receptor. The binding of insulin to its receptor causes conformational changes in the receptor leading to the activation of tyrosine kinase beta subunit. Insulin is responsible for phosphorylation of insulin receptor that leads to glucose uptake by the cells. Insulin is secreted by pancreatic islets in response to increase in blood glucose levels. Most cells of the body have insulin receptors which bind the insulin that is present in the blood circulation. When insulin is attached to insulin receptor of the cell, it initiates a cascade of events that mediates the absorption of glucose from the blood into the cell. ${ }^{3}$ Phosphorylase kinase $(\mathrm{PhK})$ is the regulatory enzyme responsible for catalyzing the rate limiting step in glycogen breakdown. PhK activates glycogen phosphorylase resulting in degradation of glycogen to glucose1-phosphate. In liver, these reactions allow for the maintenance of blood glucose, and in muscle, they lead to energy production to sustain muscle contraction. It is comprised of four different subunits with a stoichiometry of $(\alpha, \beta, \gamma, \delta) . \alpha, \beta$, and $\delta$ are regulatory, while $\gamma$ is catalytic. The $\alpha$ subunit is encoded by two different genes. ${ }^{4,5}$ The objective of the present study was to investigate the in silico antidiabetic effects of the isolated compound 1,4a,5,7a-tetrahydro-5-hydroxy-7-(hydroxymethyl) - 1 - (tetrahydro-6(hydroxymethyl) -3,4,5-trimethoxy-2H-pyran-2-yloxy) cyclopenta (c) pyran - 4 - carboxylic acid and 5,8-dihydro-7-isopentyl-2,3,5,8-tetramethoxynaphthalene-1,4,6-triol.

\section{MATERIALS AND METHODS}

\section{Collection of plant materials}

The root parts of S. tetragonum (family: Bignoniaceae) was collected from Tirunelveli district of Tamil Nadu, India and identified by the taxonomist of TBGRI and a voucher specimen (TBGRI 8282) has been deposited in the institute herbarium.

\section{Aqueous extraction of dry powder}

To prepare water extract, the powder S. tetragonum was extracted with distilled water $(5 \mathrm{~g} / 100 \mathrm{ml})$ by stirring for 4 hours and then filtering 
through filter paper (Whatman No. 1). This process was repeated thrice with the residue. The combined filtrate was freeze-dried in a lyophilizer. ${ }^{6}$

\section{Isolation of an active fraction (AF)}

The water extract of $S$. tetragonum root powder was precipitated with absolute ethanol $(1: 1 \mathrm{v} / \mathrm{v})$ and separated into precipitate and soluble fractions. The soluble fraction was subjected to the preliminary phytochemical screening and isolation of compounds. In the present study, column chromatography and preparative TLC were used for elution of two compounds. Based on IR, $\mathrm{H}^{1} \mathrm{NMR},{ }^{13} \mathrm{C}$ NMR and Mass spectrum the compound was identified as 1, 4a, 5, 7a-tetrahydro-5-hydroxy -7(hydroxymethyl) -1- (tetrahydro -6- (hydroxymethyl) -3, 4, 5-trimethoxy2H-pyran-2-yloxy) cyclopenta (c) pyran-4-carboxylic acid (Figure 1) and 5,8-dihydro-7-isopentyl-2,3,5,8-tetramethoxynaphthalene-1, 4, 6-triol (Figure 2) which was already published from our group ${ }^{7}$. The three dimensional structures of ATP- sensitive $\mathrm{K}+$ channel, Insulin receptor and phosphorylase kinase were obtained from Protein Data bank (PDB): PDB ID:2WLK, 2B4s, 2Y7J.

\section{Molecular docking}

The structures considered for the study were obtained from the isolation of active fraction and from spectral studies. 1,4a,5,7a-tetrahydro-5hydroxy-7-(hydroxymethyl)-1-(tetrahydro-6-(hydroxymethyl)-3,4,5trimethoxy-2H-pyran-2-yloxy)cyclopenta [c]pyran-4-carboxylic acid (C1) and 5,8-dihydro-7-isopentyl-2,3,5,8-tetramethoxynaphthalene1,4,6-triol (C2) were used as ligands and the structures were drawn using CHEMDRAW (Version 11). The structures of ATP- sensitive K+ channel, Insulin receptor and phosphorylase kinase were obtained from the protein data bank. Hydrogen atoms were added to the protein consistent with $\mathrm{pH} 7.0$ using the protein preparation wizard in the Schrodinger suite. ${ }^{8}$ Further, the protein's hydrogen bond network was also optimized using the wizard. The so-prepared structure was then subjected to energy minimization and the termination condition for minimization was fixed as the step when the root mean square deviation of the heavy atoms in the structure relative to the starting structure exceeded $0.3 \mathrm{~A}$. This process also ensures that the hydrogen atoms are placed in optimized geometries. The protein thus prepared was used for docking of the ligands as described below. Potential binding sites in ATP sensitive $\mathrm{K}^{+}$channel, Insulin receptor and phosphorylase kinase were predicted using the Sitemap tool in the Schrodinger suite., ${ }^{910}$ Lig Prep module (version 2.5) of the Schrodinger suite was used to generate conformers of the ligands. The ligands were then docked using the extra precision mode in the Glide module ${ }^{11-13}$ of the Schrodinger suite.

\section{RESULTS AND DISCUSSION}

Present studies provide scientific evidence that $\mathrm{C} 1$ and $\mathrm{C} 2$ strongly interact with ATP- sensitive $\mathrm{K}+$ channel, Insulin receptor and phosphorylase kinase through different residues. Figure 3 shows the XP Glide score for both the compounds for ATP- sensitive $\mathrm{K}+$ channel $(-6.981 \mathrm{Kcal} / \mathrm{mol}$ for $\mathrm{C} 1$ and $-9.425 \mathrm{Kcal} / \mathrm{mol}$ for $\mathrm{C} 2)$ which clearly suggests that both the compounds show better interaction than

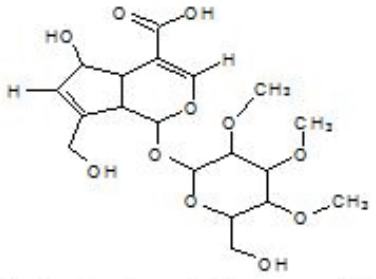

1,4a,5,7a-tetrahydro-5-hydroxy-7-(hydroxyme thyi)-1-(tetrahydro-6-(hydroxymethyi)$3,4,5$-trime thoxy-2 $H$-pyran-2-yloxy)cyclopenta[ $c]$ pyran-4-carboxylic acid

Figure 1: Structure of Compound 1 (C1).<smiles>COc1c(O)c2c(c(O)c1OC)C(OC)C(CCC(C)C)=C(O)C2OC</smiles>

5,8-dihydro-7-isopentyl-2,3,5,8-tetramethoxynaphthalene-1,4,6-triol

Figure 2: Structure of compound 2 (C2).

Compound 1

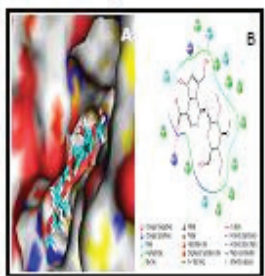

A. Surface view; B. Ligand interaction diagram
Compound 2
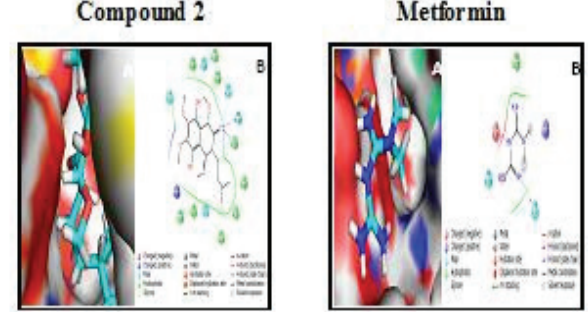

Figure 3: Interaction of compound 1, 2 and metformin with ATP-sensitive potassium channel.
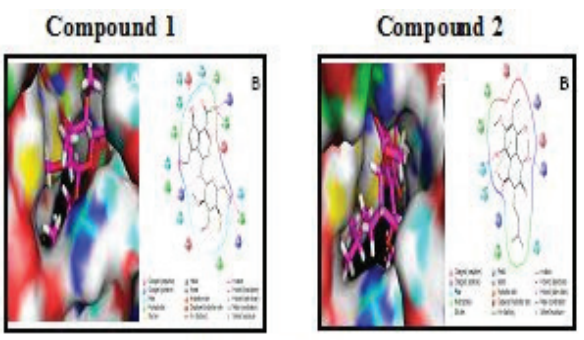

A. Surface view; B. Ligand interaction diagram

Figure 4: Interaction of compound 1, 2 and metformin with Insulin receptor.

Table 1: Glide Score of compound 1, compound 2 and standard

\begin{tabular}{|c|c|c|c|c|c|c|c|}
\hline \multirow{3}{*}{ S.No } & \multicolumn{6}{|c|}{ Docking studies } & \multirow{3}{*}{$\begin{array}{c}\text { Standard } \\
\text { Metformin }\end{array}$} \\
\hline & \multirow[b]{2}{*}{ Name of the Protein } & \multirow[b]{2}{*}{ PDB ID No. } & \multicolumn{2}{|c|}{ Site volume } & \multicolumn{2}{|c|}{ Glide score } & \\
\hline & & & C1 & C2 & C1 & $\mathrm{C} 2$ & \\
\hline 1 & ATP- sensitive $\mathrm{K}+$ channel & $2 \mathrm{WLK}$ & 812.567 & 817.026 & -6.981 & -9.425 & -2.563 \\
\hline 2 & Insulin receptor & $2 \mathrm{~B} 4 \mathrm{~s}$ & 1561.34 & 1561.34 & -7.882 & -4.62 & -3.359 \\
\hline 3 & Phosphorylase kinase & $2 \mathrm{Y} 7 \mathrm{~J}$ & 531.307 & 531.307 & -6.164 & -5.253 & -4.864 \\
\hline
\end{tabular}


Compound 1

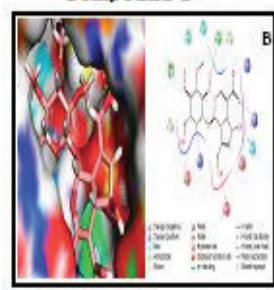

Compound 2

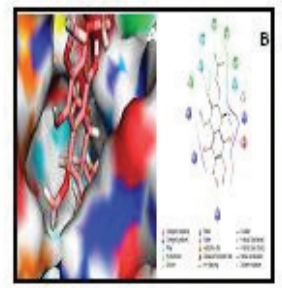

Metformin

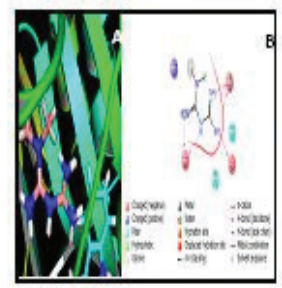

A. Surface view; B. Ligand interaction diagram

Figure 5: Interaction of compound 1, 2 and metformin with Phosphorylase kinase.

metformin (Table.1). The docking of $\mathrm{C} 1$ and C2 with ATP- sensitive $\mathrm{K}+$ channel resulted in the opening of $\mathrm{Ca}^{2+}$ channels in pancreatic $\beta$ cells causing $\mathrm{Ca}^{2+}$ influx which might have facilitated the exocytosis of insulin from pancreatic $\beta$-cells, thus constituting in lowering the blood glucose level.

Figure 4 shows the XP Glide score for both the compounds for Insulin receptor and were $-7.882 \mathrm{Kcal} / \mathrm{mol}$ for $\mathrm{C} 1$ and $-4.62 \mathrm{Kcal} / \mathrm{mol}$ for $\mathrm{C} 2$. This clearly suggests that both the compounds show better interaction than metformin (Table.1). Thus, the compounds could, possibly, activate the insulin receptor which facilitates the active absorption of glucose in skeletal muscle through GLUT4 and contributes in lowering the blood glucose.

The XP Glide score for both the compounds for phosphorylase kinase is $-6.164 \mathrm{Kcal} / \mathrm{mol}$ for $\mathrm{C} 1$ and $-5.253 \mathrm{Kcal} / \mathrm{mol}$ for C2 (Figure 5). This clearly suggests that docking of both the compounds with phosphorylase kinase lead to the inhibition of glycogenolysis by deactivating glycogen phosphorylase and thus resulting in the lowering of blood glucose level (Table 1). In this context, the isolated compounds of S. tetragonum is likely to be useful as an alternative medicine or as a combination drug. There is a need to carry on further studies leading to likely development of the isolated compound as a standardized, safe and effective phytomedicine.

\section{CONCLUSION}

The results of the above investigation shows that these active molecules are very promising for further in-depth studies leading to the development of a novel, safe and valuable anti-hyperglycemic herbal drug medicine for mono-therapy and/or combination therapy for Diabetes mellitus.

\section{ACKNOWLEDGEMENT}

The authors are thankful to SASTRA University to carry out this research work.

\section{CONFLICTS OF INTEREST}

All authors have none to declare.

\section{ABBREVIATION USED}

TLC: Thin layer Chromatography IR: Infrared; NMR: Nuclear magnetic resonance.

\section{REFERENCES}

1. Koster JC, Marshall BA, Ensor N, Corbett JA, Nichols CG. Targeted overactivity of beta cell K(ATP) channels induces profound neonatal diabetes. Cell. 2000; 100(6): 645 -54. http://dx.doi.org/10.1016/S0092-8674(00)80701-1.

2. Gribble FM, Reimann F. Sulphonylurea action revisited: the post-cloning era. Diabetologia 2003;46(7):875-91 http://dx.doi.org/10.1007/s00125-003-1143-3 PMid:12819907.

3. Ward CW, Lawrence MC). "Ligand-induced activation of the insulin receptor: a multi-step process involving structural changes in both the ligand and the receptor". Bio assays 2009;31(4):422-34. http://dx.doi.org/10.1002/bies.200800210.

4. Pickett-Gies CR, Walsh DA. In: The Enzymes. 3. Boyer PDaKEG., editor. Vol. 17. Orlando: Academic Press:1986;395-459

5. Geng Y, Derry JM, Hendrickx J, Coucke P, Willems PR, Barnard PJ.Mapping of a liver phosphorylase kinase alpha-subunit gene on the mouse $\mathrm{X}$ chromosome.Genomics. 1993;15(1):191-3. http://dx.doi.org/10.1006/geno.1993.1031; PMid:8432533.

6. Bino Kingsley R, Ajikumaran Nair S, Anil John J, Mishra Manisha, Brindha P, Subramoniam A. Anti-diabetes mellitus activity of Stereospermum tetragonum DC. in alloxan diabetic rats. J PharmacolPharmacother.2012;3(2):191-3. PMid:22629099.

7. Bino Kingsley R, Mishra M, Brindha $P$, Subramoniam A. Antidiabeticactivity of active fractions of Stereospermum tetragonum DC. and isolation of active principles. J Young Pharm. 2013;5(1):7-12. http://dx.doi.org/10.1016/j. jyp.2012.09.002; PMid:24023445 PMCid:PMC3758101.

8. MadhaviSastry G, Adzhigirey M, Day T, Annabhimoju R, Sherman W. Protein and Ligand Preparation: Parameters, Protocols, and Influence on Virtual Screening Enrichments. J Comput. Aided Mol Des. 2013;27(3):221-34. http://dx.doi. org/10.1007/s10822-013-9644-8; PMid:23579614.

9. Halgren TA. Identifying and Characterizing Binding Sites and Assessing Drugability. JChemlnf Model. 2009;49(2):377-89. http://dx.doi.org/10.1021/ ci800324m ; PMid:19434839.

10. Halgren T. New Method for Fast and Accurate Binding-site Identification and Analysis ChemBiolDrug Des.2007;69(2):146-8.

11. Friesner RA, Murphy RB, Repasky MP, Frye LL, Greenwood JR, HalgrenTA, SanschagrinPC, Mainz DT. Extra Precision Glide: Docking and Scoringlncorporating a Model of Hydrophobic Enclosure for Protein-Lig and Complexes. J Med Chem. 2006;49(21):6177-96. http://dx.doi.org/10.1021/jm051256o; PMid:17034125.

12. Halgren TA, Murphy RB, Friesner RA, Beard HS, Frye LL, Pollard WT,Banks, JL Glide: A New Approach for Rapid, Accurate Docking and Scoring. 2. Enrichment Factors in Database Screening. J Med Chem.2004;47(7):1750-9. http://dx.doi. org/10.1021/jm030644s ; PMid:15027866.

13. Friesner RA, Banks JL, Murphy RB, Halgren TA, Klicic JJ, Mainz DT, Repasky MP, Knoll EH, Shelley M, Perry JK, Shaw DE, Francis P, Shenkin PS. Glide: A New Approach for Rapid, Accurate Docking and Scoring. 1. Method and Assessment of Docking Accuracy. J Med Chem.2004; 47(7):1739-49. http://dx.doi. org/10.1021/jm0306430; PMid:15027865.

Article History: Submission Date: 04-07-16; Revision Date: 02-09-16; Accepted Date: 01-10-16.

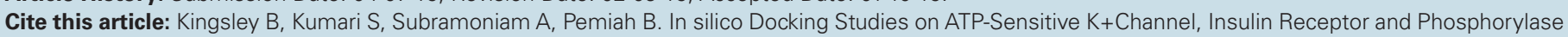
kinase Activity by Isolated Active Principles of Stereospermum tetragonum DC. J Young Pharm. 2017;9(1):124-6. 